\title{
Quality of Life in Chronic Myeloid Leukemia Patients in the Era of Generic Imatinib
}

\author{
Jenerik İmatinib Çağında Kronik Myeloid Lösemi Hastalarında Yaşam \\ Kalitesi
}

\author{
Abide Günnur BALCI GUCLU' ${ }^{1}$, Nur OGUZ DAVUTOGLU² ${ }^{2}$ Beyhan DURAK ARAS ${ }^{3}$, Eren GUNDUZ ${ }^{2}$ \\ ${ }^{1}$ Eskisehir Osmangazi University School of Medicine Department of Internal Medicine, Eskisehir, Turkey \\ ${ }^{2}$ Eskisehir Osmangazi University School of Medicine Department of Hematology, Eskisehir, Turkey \\ ${ }^{3}$ Eskisehir Osmangazi University School of Medicine Department of Genetics, Eskisehir, Turkey
}

\section{ÖZET}

GİRIŞ ve AMAÇ: Günümüzde birçok kronik miyelod lösemi (KML) hastası için primer tedavi imatinib mesilattır. İkinci kuşak tirozin kinaz inihibitörü (TKİ) olan dasatinib ve nilotinib 1. basamakta da etkin olmakla birlikte sıklıkla dirençli ya da intoleran hastalarda kullanılır. Tedavi oral olarak kullanılan bu ilaçlara sıkı uyum ve düzenli kan kontrolleri yapılmasını gerektirir. Ömür boyu tedavi yanısıra düzenli kontroller hastanın yaşam kalitesini etkilemektedir. Yeni kuşak tirozin kinaz inhibitörleriyle yaşam kalitesine ait veriler daha azdır. Ayrıca ülkemizdeki KML hastalarının hemen tümü fiyat farkı nedeniyle artık orijinal olmayan imatinib kullanmaktadır. Çalışmamızda KML tanısıyla takip ve tedavisi yapılan ve halen TKİ (imatinib, dasatinib, nilotinib) kullanmakta olan hastaların yaşam kalitelerinin değerlendirilmesi amaçlanmıştır

YÖNTEM ve GEREÇLER: Bu çalışmada KML tanısıyla takip edilen toplam 120 hastanın yaşam kalitesi değerlendirildi.Yaşam kalitesini değerlendirmek amacıyla EORTC QLQ-CML24 ve EORTC QLQ-C30 (versiyon 3.0) ölçekleri kullanıldı.

BULGULAR: Nilotinib için hesaplanan uykusuzluk ölçeği imatinib ölçeğinden anlamlı oranda düşük bulundu $(\mathrm{p}=0.027)$. İmatinib kullanan hastalar için hesaplanan günlük hayata etki ölçeği dasatinib kullanan hastalar ile kıyaslandığında daha düşüktü ( $\mathrm{p}=0.007)$. Diğer parametreler için gruplar arasında fark saptanmadı.

TARTIŞMA ve SONUÇ: Çalışmamızda jenerik imatinib, dasatinib ve nilotinib alan kronik miyeloid lösemi hastaları arasında yapılan karşılaştırma sonuçlarının büyük oranda benzer bulunması daha potent olan 2.kuşak TKİ'lerin imatinib kadar iyi tolere edildiğini ve yaşam kalitesine benzer etki yaptığını düşündürmüştür.

Anahtar Kelimeler: Kronik Myeloid Lösemi, yaşam kalitesi, imatinib, dasatinib, nilotinib

\begin{abstract}
INTRODUCTION: The first line treatment for chronic myeloid leukaemia (CML) is still imatinib mesylate in many countries. Dasatinib and nilotinib are also effective in first line treatment but often used in resistant or intolerant patients. The treatment requires strict drug compliance and regular blood tests. Lifelong treatment as well as regular controls may negatively affect the quality of life. The aim of this study was to evaluate the quality of life of CML patients taking tyrosine kinase inhibitors (TKI).

METHODS: A total of 120 patients were included in the study and divided into 3 groups according to the TKI they take generic imatinib $(n=72)$, dasatinib $(n=23)$ or nilotinib $(n=25)$. EORTC QLQ-CML24 and EORTC QLQC30 (version 3.0) scales were used to evaluate the quality of life.

RESULTS: Insomnia in nilotinib group was lower than the dasatinib group (16.00 \pm 23.80 vs $28.70 \pm 35.25$, $\mathrm{p}=$ 0.027). The satisfaction with care information of imatinib group was lower than dasatinib group (75.46 $\pm 17.00 \mathrm{vs}$ $84.78 \pm 20.66, p=0.007)$. No difference was found between the 3 groups for other parameters.

DISCUSSION AND CONCLUSION: The comparison of chronic myeloid leukemia patients under generic imatinib, dasatinib and nilotinib suggested that the second generation TKIs are generally well tolerated and have nearly similar effects with imatinib on quality of life.

Keywords: chronic myeloid leukemia, quality of life, imatinib, dasatinib, nilotinib
\end{abstract}




\section{INTRODUCTION}

Chronic myeloid leukemia (CML) is the first disease in which a specific karyotypic abnormality wasdetected, and is the most wellcharacterized leukemia type at molecular level $(1,2)$. It contributes $20 \%$ of alladult leukemias (3). The annual incidence has been determined as 1.6 / 100000 (4).CML cases are usually diagnosed at achronic stage in which the disease can be effectively controlled by standard treatment and the patients have little or no symptomsat diagnosis(5).

Imatinib, the first oral target-specific agent in the treatment of CML, has transformed the disease into a chronic disease with long remission periods. After the approval of imatinib as the initial treatment of CML; second generation tyrosine kinase inhibitors (TKI), bosutinib, ponatinib and non-TKI omacetaxine were approved for the treatment of refractory CML patients in 2012 (6). Althoughdasatinib and nilotinib are also effective in as first line therapy, they are often used in resistant or intolerant patients in many countries.

Whilethe 5-year relative survival rate of CML patients was found21\% between 1973-1979, this rate increased to $80 \%$ in patients diagnosed between 2001 and 2008 due to progress achieved through TKIs (7). It is estimated that the number of CML patients will be more than 180000 in 2050 in the USA (8).

Originator imatinib has been used in Turkey since 2003. However, the generic formulations of drugs are increasing, since treatment costs give a great additional burden to the national economy and generic imatinib formulations have been used since 2012 (9).

It has been shown that imatinib is generally well-tolerated and the most important side effect that negatively affects the quality of life is chronic fatigue. Data on new generation TKIsisscarce.We believe that the quality of life data regarding generic imatinib and new generation TKIs, are important. In our study, we aimed to evaluate the quality of life of CML patients who are still taking a TKI (imatinib, dasatinib or nilotinib).

\section{MATERIALS and METHODS}

In this study, a total of 120 patients with CML were evaluated. Sociodemographic charactersitics and laboratory results were retrospectively obtained from the existing records, and the quality of life was evaluated during the last routine control visit.EORTC QLQ-CML24 and EORTC QLQ-C30 (version 3.0) scales were used to evaluate the quality of life.The study was approved by local ethical committee and is in accordance with the current version of the Helsinki Declaration.

EORTC-QLQ-C30 (version 3.0) has 30 items. Measured areas are; physical, role, cognitive, emotional, social and global quality of life. High overall score refers to better function. High symptom score expresses higher symptom distress. TheEORTC QLQ-C30 (version 3.0) has been found reliable and valid for Turkish patients (10).

Efficace et al. (11) have published EORTC QLQ-CML24 for CML patients in 2014. EORTC QLQ-CML24 is used with the EORTC QLQ-C30. Twenty four items are added to QLQ-C30 (54 itemstotally). Measured areas are; symptoms associated with illness and treatment, psychosocial issues, infertility, body image, treatment program distress and satisfaction.

\section{Statistical Analysis}

All statistical analyses were performed by using SPSS v.21.0 (IBM Corp., Armonk, NY, USA). Pearson Exact Chi-square test was performed on categorical data comparison of the patients andindependent sample $t$ test was applied to compare the differences between groups. Data are expressed either as frequencies $(n)$, mean \pm standard deviation $(\bar{x} \pm s d)$. Pearson correlation analysis was applied to determine the relationship between laboratory parameters and the scales. A $p$-value $<0.05$ was considered statistically significant.

\section{RESULTS}

All patients participated in the survey were at chronic stage. The mean age was $55 \pm 14.4$ years. The mean duration of disease at the time of the survey was $6.7 \pm 4.5$ years. Fifty six percent of the patients were female and $44 \%$ were male. The sokal risk wasfound low in $69 \%$ and moderate in $31 \%$ of the patients.

The Eastern Cooperative Oncology Group (ECOG) performance score was 0 in 105 patients, 1 in 12 patients, and 2 in 3 patients. Responses were recorded as complete hematologic response (CHR) in 87\% and major molecular response (MMR) in $81 \%$ of patients. Seventy (60\%) patients were using imatinib, 25 
(21\%) patients were using nilotinib and 23 (19\%) patients were using dasatinib at the time of evaluation.

When we evaluated hematological and biochemical paramaters most parameters were found similar between 3 groups. The different parameters were as follows:

1) Mean corpuscular volume (MCV) was highest in imatinib group (91.31 $\pm 5.11 \mathrm{fl}$ for imatinib, $84.10 \pm 6.71 \mathrm{fl}$ for dasatinib, $86.82 \pm 6.72 \mathrm{fl}$ for nilotinib $(\mathrm{p}=0.000)$.

2) Calcium was lowest in dasatinib group $(10.41 \pm 10.62 \mathrm{mg} / \mathrm{dl}$ for imatinib, $9.11 \pm 0.50$ $\mathrm{mg} / \mathrm{dl}$ for dasatinib, $9.30 \pm 0.58 \mathrm{mg} / \mathrm{dl}$ for nilotinib) ( $\mathrm{p}=0.01)$.

3) Total protein was lowest in imatinib group $(6.76 \pm 0.62 \mathrm{~g} / \mathrm{dl}$ for imatinib, $7.13 \pm 0.49 \mathrm{~g} / \mathrm{dl}$ for dasatinib, $7.33 \pm 0.46 \mathrm{~g} / \mathrm{dl}$ for nilotinib) $(\mathrm{p}=0.000)$.

4) Total bilirubin was highest in nilotinib group $(0.38 \pm 0.17 \mathrm{mg} / \mathrm{dl}, 0.52 \pm 0.31 \mathrm{mg} / \mathrm{dl}, 0.84 \pm 0.62$ $\mathrm{mg} / \mathrm{dl}$ for nilotinib) $(\mathrm{p}=0.000)$.

5) Gamma glutamil transpeptidase (GGT) was highest in nilotinib group $(16.41 \pm 7.96 \mathrm{U} / \mathrm{L}$ for

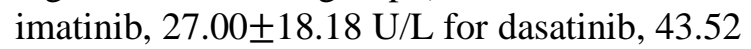
$\pm 29.53 \mathrm{U} / \mathrm{L}$ for nilotinib) ( $\mathrm{p}=0.000)$.

6) Alkaline phosphatase (ALP) was highest in nilotinib group $(74.02 \pm 35.52 \mathrm{U} / \mathrm{L}$ for imatinib, $69.75 \pm 31.60 \mathrm{U} / \mathrm{L}$ for dasatinib, $86.84 \pm 19.21$ $\mathrm{U} / \mathrm{L}$ for nilotinib) $(\mathrm{p}=0.003)$.

7) Creatine kinase(CK) was highest in imatinib group (206.10 $\pm 194.80 \mathrm{U} / \mathrm{L}$ for imatinib, 176.35 $\pm 134.20 \mathrm{U} / \mathrm{L}$ for dasatinib, $94.64 \pm 43.23$ $\mathrm{U} / \mathrm{L}$ for nilotinib) $(\mathrm{p}=0.000)$.

8) Amylase was highest in dasatinib group (70.07 $\pm 20.49 \mathrm{U} / \mathrm{L}$ for imatinib, 81.95 \pm 33.54 $\mathrm{U} / \mathrm{L}$ for dasatinib, $63.52 \pm 19.72 \mathrm{U} / \mathrm{L}$ for nilotinib) $(\mathrm{p}=0.035)$.

The satisfaction with care information was higher in dasatinib group when compared with imatinib (75.46 \pm 17.00 for imatinib, $84.78 \pm 20.66$ for dasatinib, $p=0.007$ ). All other scales were found similar between groups. There were no correlations between scales and haematological and/or biochemical parameters and molecular responses.

\section{DISCUSSION}

In this study, we evaluated $120 \mathrm{CML}$ patients totally. Responses were recorded as CHR in $87 \%$ and MMR in $81 \%$ of patients. This finding was related with the shorter treatment duration at the time of evaluation for some patients.

When we examined biochemical parameters we saw that calcium was lowest in dasatinib group so we suggest that patients under dasatinib should be monitored more carefully for calcium supplementation.Highest bilirubin, GGT and ALP in nilotinib group was correlated with the well known adverse event profile of nilotinib.Lowest protein and the highest MCV in imatinib group suggested an effect of imatinib on protein synthesis.

Highest CK in imatinib group was correlated with the observation of more frequent muscle cramps in our patients under imatinib. Although pancreatitis is usually observed with nilotinib, amylase was highest in dasatinib group but this was not clinically significant.

World Health Organization (WHO) defines health as; physical, spiritual and social aspects of a complete well-being. Based on this definition, the goal of health services is not only to improve or prevent diseases, but also to provide a high quality of life for the patients to maintain their role in the society.

Patient-reported outcome (PRO) tools for measuring the quality of life in CML patients treated with TKIs are as follows:

1. General Tools, Non-Specific to cancer:European Quality of Life 5 Dimensions (EQ-5D), Medical Outcomes Study 36-Item Short Form Health Survey (SF-36)

2. Tools specific to cancer, non-specific to CML:Cancer Therapy Satisfaction Questionnaire (CTSQ), EORTC Quality of Life Questionnaire (EORTC QLQ-C30), Functional Assessment of Cancer Therapy-General (FACT-G), Functional Assessment of Cancer Therapy - Biologic Response Modifiers (FACT-BRM), Functional Assessment of Cancer Therapy-Anti angiogenesis Therapy (FACT-Anti-A)

3. Specific Tools for Leukaemia or CML:Functional Assessment of Cancer Therapy - Leukaemia (FACT-Leu), MDASICML, EORTC QLQ-CML24 (10-12).

In our study, the life quality of 120 patients with CML was evaluatedwith EORTC QLQ-C30 (version 3.0) and EORTC QLQ CML-24 scales.To our knowledge there is no similar study in the literature, comparing 3 treatment groups (imatinib, dasatinib and nilotinib) and using the same scales. 
Ugur et al. (13) evaluated the quality of life of patients under dasatinib and nilotinib by only EORTC QLQ-C30 questionnaire. In this study, the general health scale was found lower than dasatinib for nilotinib. The physical function scale was similar for imatinib, dasatinib and nilotinib. There was no significant difference between the groups for the role function scale. The emotional and perceptual function scale and the symptom fatigue scale was lower than dasatinib for nilotinib, no difference was found between groups for social function and nauseavomiting scales.Uğur et al. (13) found no significant difference between the patients using imatinib, dasatinib, nilotinib and all 2nd generation TKIs for symptom pain scale. They could not find a significant difference between the groups under imatinib, dasatinib, nilotinib and all 2nd generation TKIs, for dyspnea symptom scale and for symptom loss of appetite, constipation, diarrhea and financial difficulties scales also.In our study, the results were found similar for all groups.

Unnikrishnan et al. (14) evaluated $221 \mathrm{CML}$ patients with the scales used in our study but evaluated only patients using imatinib. The general health scale was higher in patients who show adherence to the treatment than those who do not. The physical function and role function scales were found higher in patients who are adherent with imatinib. On the other hand, the symptom nausea and vomiting scale was lower in adherent patients. The symptom pain scale was higher in patients who were adherent than those who were not. In our study, we did not evaluate results according to treatment adherenceso it is difficult to make comment.

AlthoughUgur et al. (13) could not found a significant difference between the groups for the symptom insomnia scale, insomnia scale in nilotinib group was lower than the dasatinib groupin our study (16.00 \pm 23.80 for nilotinib and 28.70 \pm 35.25 for dasatinib) ( $p=$ 0.027).Concomittant drug side effects may have an impact on this point but we unfortunately did not examine the side effects specifically.

The satisfaction with care information was higher in dasatinib group when compared with imatinib (75.46 \pm 17.00 for imatinib, $84.78 \pm 20.66$ for dasatinib, $\mathrm{p}=0.007)$. Maybe this difference can be explained by the relationship with food intake because it is easier to inform the patient if the drug has no relationship with the stomach being empty or not. All other scales were found similar between groupssuggesting that the more potent 2 nd generation TKIs were well tolerated as imatinib and had a similar effect on quality of life.

Unfortunately, comparisons could be made mainly with 2 studies. Distinct results were suggested to be associated with the size of patient population, different sociodemographic characteristics, lack of consideration of adherence to therapy, and differences in the imatinib preparations. Since heterogeneous patient groups and different scales were used in other available quality of life studies, direct comparison was not found appropriate. However, we believe that our study may raise the interest for further studies with the same scales.

In conclusion, a good quality of life is a rising target of therapy for all patients. The number of studies investigating the quality of life with first and second generation TKIs can lead to developments in the era of individualized therapy in CML.

\section{REFERENCES}

1. Faderl S, Talpaz M, Estrov Z, O'Brien S, Kurzrock R, Kantarjian HM. The biology of chronic myeloid leukemia. N Engl J Med 1999;341:164-172.

2. Talpaz M, Kantarjian HM, McCredie KB, Keating MJ, Trujillo J, Gutterman J. Clinical investigation of human alpha interferon in chronic myelogenous leukemia. Blood 1987;69:1280-1288.

3. Quintas-Cardama A, Cortes JE. Chronic myeloid leukemia: diagnosis and treatment. Mayo Clin Proc 2006;81:973-988.

4. Schiffer CA. BCR-ABL tyrosine kinase inhibitors for chronic myelogenous leukemia. N Engl J Med 2007;357:258-265.

5. Dalziel K, Round A, Stein K, Garside R, Price A. Effectiveness and cost-effectiveness of imatinib for first-line treatment of chronic myeloid leukaemia in chronic phase: a systematic review and economic analysis. Health Technol Assess 2004;8:iii, 1-120.

6. Cortes J, Lipton JH, Rea D, Digumarti R, Chuah C, Nanda N, Benichou AC, Craig AR, Michallet M, Nicolini FE, Kantarjian H; Omacetaxine 202 Study Group. Phase 2 study of subcutaneous omacetaxine mepesuccinate after TKI failure in patients with chronicphase CML with T315I mutation. Blood 2012;120:25732580.

7. Bjorkholm M, Ohm L, Eloranta S, Derolf A, Hultcrantz M, Sjoberg J, Andersson T, Hoglund M, Richter J, Landgren O, Kristinsson SY, Dickman PW. Success story of targeted therapy in chronic myeloid leukemia: a population-based study of patients diagnosed in Sweden from 1973 to 2008. J Clin Oncol 2011;29:25142520.

8. Richard A Van Etten M. Clinic manifestations 
and diagnosis of chronic myeloid leukemia2014.

9. Eskazan AE, Ayer M, Kantarcioglu B, Arica D, Demirel N, Aydin D, Yalnız FF, Elverdi T, Salihoglu A, Ar MC, Ongoren Aydın S, Baslar Z, Aydin Y, Tuzuner N, Ozbek S, Soysal T. First line treatment of chronic phase chronic myeloid leukaemia patients with the generic formulations of imatinib mesylate. $\mathrm{Br} \mathrm{J}$ Haematol 2014;167:139-141.

10. Guzelant A, Goksel T, Ozkok S, Tasbakan S, Aysan T, Bottomley A. The European Organization for Research and Treatment of Cancer QLQ-C30: an examination into the cultural validity and reliability of the Turkish version of the EORTC QLQ-C30. Eur J Cancer Care (Engl). 2004;13:135-144.

11. Efficace F, Baccarani M, Breccia M, Saussele S, Abel G, Caocci G, Guilhot F, Cocks K, Naeem A, Sprangers M, Oerlemans C, Chie W, Castagnetti F, Bombaci F, Sharf G, Cardoni A, Noens L, Pallua S, Salvucci M, Nicolatou-Galitis O, Rosti G, Mandelli F. International development of an EORTC questionnaire for assessing health-related quality of life in chronic myeloid leukemia patients: the EORTC QLQ-CML24. Qual Life Res 2014;23:825-836.

12. Hahn EA, Glendenning GA, Sorensen MV, Hudgens SA, Druker BJ, Guilhot F, Larson RA, O'Brien SG, Dobrez DG, Hensley ML, Cella D; IRIS Investigators. Quality of life in patients with newly diagnosed chronic phase chronic myeloid leukemia on imatinib versus interferon alfa plus low-dose cytarabine: results from the IRIS Study. J Clin Oncol 2003;21:2138-2146.

13. Ugur MC, Kutbay YB, Ozer Kaya O, Ceylan C. Assessment of Quality of Life of Chronic Myeloid Leukemia Patients by Using the EORTC QLQ-C30. Turk J Haematol 2017;34:197-199.

14. Unnikrishnan R, Veeraiah S, Mani S, Rajendranath R, Rajaraman S, Vidhubala Elangovan GS, Radhakrishnan V, Ganesan TS, Sagar TG, Ganesan P. Comprehensive Evaluation of Adherence to Therapy, Its Associations, and Its Implications in Patients With Chronic Myeloid Leukemia Receiving Imatinib. Clin Lymphoma Myeloma Leuk 2016;16:366-371 e3. 